\title{
Literary Linkage: The Naming of Serial Novels
}

\section{Adrian Room}

\begin{abstract}
While many writers of serial novels do not devise mutually related titles for their works, some do, especially in popular fiction such as crime novels and children's literature. The titles may be linked either by repetition or by a more subtle device such as variations on a generic theme.
\end{abstract}

\section{$* * * * *$}

First, although it may well not be needed, a definition. A serial novel is one of a number, usually by a single author, in which certain characters recur and in which in particular the main character plays an important role in the successive books. Familiar examples of serial novels are the detective novels by Agatha Christie featuring the detective Hercule Poirot, or those by Michael Innes in which Sir John Appleby is the central figure. Serial novels also include adventure stories, such as the famous ones about Tarzan by the American Edgar Rice Burroughs. Nor should one overlook the gentle books by "Miss Read" (Dora Jessie Saint), in which the recurring characters are as much the English fictional village of Fairacre and community of Thrush Green as the people who live and work in these places, notably Miss Read herself, as the village schoolmistress.

Authors of serial novels inevitably have their devotees, many of whom eagerly await the next installment. But the authors themselves will hope to attract new readers, especially those who may have heard of earlier titles but not actually read them.

Both old and new readers will need to be advised of an author's latest serial novel, and of a further episode in the life and times of its familiar characters. Routine publicity and the author's name will doubtless suffice to make the new title known. But some authors like to title their new novels in such a way that it clearly links with previous books. This present paper is a consideration of how they actually do so. ${ }^{1}$

It should be said straightaway that most popular authors do not. That is, the titles of their books have no common theme. Agatha Christie's Miss Marple stories, for example, featuring the elderly spinster detective, begin their run as Murder at the Vicarage (1930), Body in the Library (1942), The 
Thirteen Problems (1942), The Moving Finger (1943), A Murder is Announced (1950), and so on, including some agreeable literary quotations such as The Mirror Crack'd From Side to Side (1962), but with no thematic link between them. Burroughs, on the other hand, started off as he meant to go on by repeating the name of his hero in successive titles: Tarzan of the Apes (1914), The Return of Tarzan (1915), The Beast of Tarzan (1916), and so on, until Tarzan and the Jewels of Opar (1918) gave the Tarzan and the matrix that was more or less consistently adhered to from that year. Of his twenty-five titles, twelve have this formula, and they all include the name of the hero.

The repetition of a word, phrase, or name in a title is thus the obvious way to link novels in a series. The word or phrase may be fairly unoriginal. Death or Murder is a favorite in crime fiction, as is Case of the. The British detective writer Christopher Bush had fifty Case of the titles in his Ludovic Travers series, beginning with the Case of the Green Felt Hat and ending with Case of the Prodigal Daughter in 1967, the year of his death. The British suspense writer "Robert Conington Galway" (Philip McCutchan) preferred Assignment, starting with Assignment New York (1961) and continuing with Assignment London (1963), Assignment Andalusia (1964), Assignment Gaolbreak (1966), and the like.

For his popular stories of medical life, the British doctor "Richard Gordon" (Gordon Ostlere) incorporated Doctor in most of his titles, usually followed by a prepositional phrase: Doctor in the House (1952), Doctor at Sea (1954), Doctor at Large (1955), Doctor in Love (1957), and others. These particular titles became well known from the resultant movie and television versions. Most common, however, is the repetition of the leading character's name (or nickname), as with Tarzan. "Leslie Charteris" (Leslie Charles Bowyer Yin), the British (naturalized American) crime writer, included The Saint in the titles of all but a handful of his forty-book Saint series, from Enter the Saint (1936) onwards. Some stories that originally did not include the nickname of the detective, real fictional name Simon Templar, had it incorporated retrospectively, once the series had become established. Thus Charteris' first book in the series, Meet the Tiger (1928), later became The Saint Meets the Tiger, while the third, The Last Hero (1936), was renamed The Saint Closes the Case.

Case of the (or a similar phrase) was fairly widely adopted by crime writers. The American mystery author Erle Stanley Gardner began his Perry Mason series with The Case of the Velvet Claw (1933) and concluded triumphantly no less than eighty-nine titles later with The Case of the Postponed Murder (1977). The name of the case is usually nicely incongruous, such as The Case of the Perjured Parrot (1939) or The Case of the Cautious Coquette 
(1955). As these two examples also illustrate, the couplet (adjective and noun) that forms the essence of the title is frequently alliterative. The first such was the third in the series, The Case of the Lucky Legs (1934), and of the eighty-nine titles no less than forty-six employ this memorable device. This feature helps to distinguish Gardner's novels from those of other crime writers using the Case of the formula.

The British detective novelist Alan Hunter punned on the name of his hero Superintendent George Gently (presumably devised for the purpose) to provide the titles of many of his books. They begin with (you guessed it) Gently Does It (1955) and include Gently Down the Stream (1957), Landed Gently (1958) - a double pun, suggesting "landed gentry," Gently in the Sun (1959), and Gently Continental (1968). In the 1980s, however, Hunter abandoned the theme, after a run of twenty-five, and switched to conventional titles that did not incorporate the detective's name.

The repeated name may well be that of a place rather than a person. The Thrush Green books by "Miss Read," already mentioned, begin with Thrush Green itself in 1960 and continue with the name concluding every title, from Winter in Thrush Green (1961) onwards. Friends at Thrush Green (1990) is one of the latest in the series. A similar placename repetition is found for the Falconhurst novels of Kyle Onstott, dealing with a slave estate in Louisiana, although Master of Falconhurst (1964), the earliest title with the name, is the third in the series. The first two were Mandingo (1960) and Drum (1963).

The thematic titling may be indicated more subtly than by mere repetition, however. The British writer and former agony aunt Clare Rayner has thus named all her Performers series for London streets or districts, beginning with Gower Street in 1973 and continuing with The Haymarket (1974), Paddington Green (1975), Soho Square (1976), Bedford Row (1977), Long Acre (1978), Charing Cross (1979), The Strand (1980), Chelsea Reach (1982), Shaftesbury Avenue (1983), Piccadilly (1985), and Seven Dials (1986). The twelve books comprise a family saga set in the nineteenth and twentieth centuries.

The American mystery writer Frances Crane preferred colors for her series about the smart young detectives Pat and Jean Abbott. The twenty-six titles are worth quoting in their bright splendor: The Turquoise Shop (1943), The Golden Box (1944), The Yellow Violet (1944), The Pink Umbrella (1944), The Applegreen Cat (1945), The Amethyst Spectacles (1946), The Indigo Necklace (1946), The Shocking Pink Hat (1948), The Cinnamon Murder (1949), Murder on the Purple Water (1949), Black Cypress (1950), Flying Red Horse (1951), The Daffodil Blonde (1951), The Polkadot Murder (1952), Death in the Blue Hour (1952), Thirteen White Tulips (1953), Murder 
in Bright Red (1954), The Coral Princess Murders (1955), Death in Lilac Time (1955), Horror on the Ruby X (1956), The Ultra-Violet Window (1957), The Grey Stranger (1958), The Buttercup Case (1958), Death-Wish Green (1960), Amber Eyes (1962), Body Beneath a Mandarin Tree (1965).

"Francis Beeding" (the joint pseudonym of English authors Hilary St. George Saunders and John Leslie Palmer) adopted cardinal numbers for the titles of the Colonel Granby series published in the 1930s: One Sane Man, The Two Undertakers, Three Fishers, Four Armourers, Five Flamboys, Six Proud Walkers, Seven Sleepers, Eight Crooked Trenches, Nine Waxed Faces, The Ten Holy Horrors, Eleven Were Brave, The Twelve Disguises, There Are Thirteen.

In his Dr. Palfrey novels, the prolific British crime writer John Creasey devised a fairly distinctive "definite article plus noun" set of titles for the last twelve or so books in the series, starting with The Flood in 1958 and continuing with The Drought (1959), The Terror (1962) - although subtitled The Return of Dr. Palfrey, The Depths (1963), The Sleep (1964), The Inferno (1965), The Famine (1967), The Blight (1968), The Oasis (1970), The Smog (1970), The Unbegotten (1971), and The Insulators (1972), but concluding with The Voiceless Ones (1973).

The popular British writer on veterinary life "James Herriot" (James Wight) has adopted phrases from the children's hymn "All Things Bright and Beautiful" to link the titles of his books, alternating them with titles incorporating the word Vet. His device with the latter is to substitute the word (more subtly than might be supposed) for the name of an animal in a familiar proverb or catch-phrase. One thus has, in chronological order: All Creatures Great and Small (1972), Let Sleeping Vets Lie (1973), All Things Bright and Beautiful (1973), Vet in Harness (1974), Vets Might Fly (1976), Vet in a Spin (1977), and The Lord God Made Them All (1981). However, All Creatures Great and Small was not a new book, but a new title for a combined American edition of two earlier books, If Only They Could Talk (1970) and It Shouldn't Happen to a Vet (1972).

Crime and suspense novelists, not surprisingly, like sometimes to adopt a more intellectual theme for the titles of serial novels. The British writer "Simon Rattray" (Elleston Trevor), best known for The Flight of the Phoenix (1964), punningly adopted chess terms for titles in his Hugo Bishop series: Knight Sinister (1951), Queen in Danger (1952), Bishop in Check (1953), Rook's Gambit (1954), and Pawn in Jeopardy (1955). The last two titles, however, were originally respectively Dead Silence and Dead Circuit, so did not conform to the original theme.

The British spy writer Angus Ross has used a distinctive formula of "placename plus common noun" for his Marcus Farrow novels. Many of 
the names are those of British provincial cities. The first was The Manchester Thing (1970). Subsequent titles have included The Huddersfield Job (1971), The London Assignment (1972), The Aberdeen Conundrum (1977), and The Darlington Jaunt (1985).

The American mystery writer Lawrence Treat (who, as Lawrence A. Goldstone, legally adopted his pseudonym in the $1940 \mathrm{~s}^{2}$ ) took to a more unusual thematic device in his "alphabet" series, featuring Mitch Taylor and Jub Freeman. He began with $B$ as in Banshee in 1940, then went on (not entirely in alphabetical order, however) as $D$ as in Dead (1941), $H$ as in Hangman (1942), $O$ as in Omen (1943), $V$ as in Victim (1945), $H$ as in Hunted (1945), $Q$ as in Quicksand (1947), $F$ as in Flight (1949), and $T$ as in Trapped (1949). A short story, $L$ as in Loot, also appeared in Ellery Queen's Mystery Annual in 1965.

"Andrew York" (Christopher Robin Neale), a British novelist, selected job-style titles for the novels in his Jonas Wilde series: The Eliminator (1965), The Co-ordinator (1966), The Predator (1968), The Deviator (1969), The Dominator (1970), The Infiltrator (1970), The Expurgator (1971), The Assassinator (1972), The Captivator (1973), The Fascinator (1975).

It is perhaps in children's fiction, however, where the most obvious thematic devices are found. The British poet and author John Pudney produced the following in the Fred and I series from 1950: Saturday Adventure, Sunday Adventure, Monday Adventure, Tuesday Adventure, Wednesday Adventure, Thursday Adventure, Friday Adventure, Spring Adventure, Summer Adventure, Autumn Adventure, Winter Adventure. He starts the series not with the first day of the week but with the one most likely for a juvenile escapade.

Enid Blyton, the doyenne of popular British children's writers, mainly adopted the repetitive device, especially for her Famous Five series (Five on a Treasure Island and others) and for the Noddy series (Noddy and His Car and the like), but used a chronological theme for the Malory Towers school stories: First Term at Malory Towers, Second Term at Malory Towers, Third Year at Malory Towers, Upper Fourth at Malory Towers, In the Fifth at Malory Towers, and Last Term at Malory Towers. An earlier and more famous example of children's serial novels was that of the much loved Katy books by the American author "Susan Coolidge" (Sarah Chauncy Woolsey): What Katy Did (1872), What Katy Did at School (1873), and What Katy Did Next (1886).

In Britain, Richmal Crompton gained fame through her William series. Every one of the forty-odd titles ${ }^{3}$ contains the name of the scruffy but resourceful schoolboy, from Just - William (1922), with its carefully 
placed dash, through More William (1922), William Again (1923) and Sweet William (1936) to William the Lawless (1970). About half the titles follow the William-The model, beginning with William-The Fourth (1924) - a gentle pun: the book was the fourth in the series - and inevitably including William - The Conquerer (1926).

The Canadian children's writer L. M. Montgomery employed a looser thematic structure for the titles of her novels, beginning with the popular Anne of Green Gables (1908). But the name of the heroine or that of the community where she lives recurs regularly in most of the sequels: Anne of Avonlea (1909), Chronicles of Avonlea (1912), Anne of the Island (1912), Anne's House of Dreams (1915), Further Chronicles of Avonlea (1920), Anne of Windy Poplars (1936), and Anne of Ingleside (1939).

Whatever the series, such titles give a clear signal that the devoted reader can expect "more of the same," and so plunge in accordingly.

\section{Stamford, Lincolnshire, England}

\section{Notes}

1. Most of the titles in this paper are taken from the collections of Gardner and Hicken, with recent titles from such annual publications as Who's Who and People of Today. Gardner's and Hicken's compilations are just two of the volumes in a continuing and regularly updated series, usually available for consultation in public libraries.

2. Additional details about crime and mystery writers are to be found in Keating, although only selective titles are cited.

3. Listed in full in Cadogan.

\section{Works Cited}

Cadogan, Mary. The William Companion. London: Macmillan, 1990.

Gardner, Frank, comp. Sequels. 5th ed. London: Association of Assistant Librarians, 1967.

Hicken, Marilyn E., comp. Sequels. 8th ed. London: Association of Assistant Librarians, 1986.

Keating, H. R. F., ed. Whodunit? A Guide to Crime, Suspense \& Spy Fiction. London: Windward, 1982. 